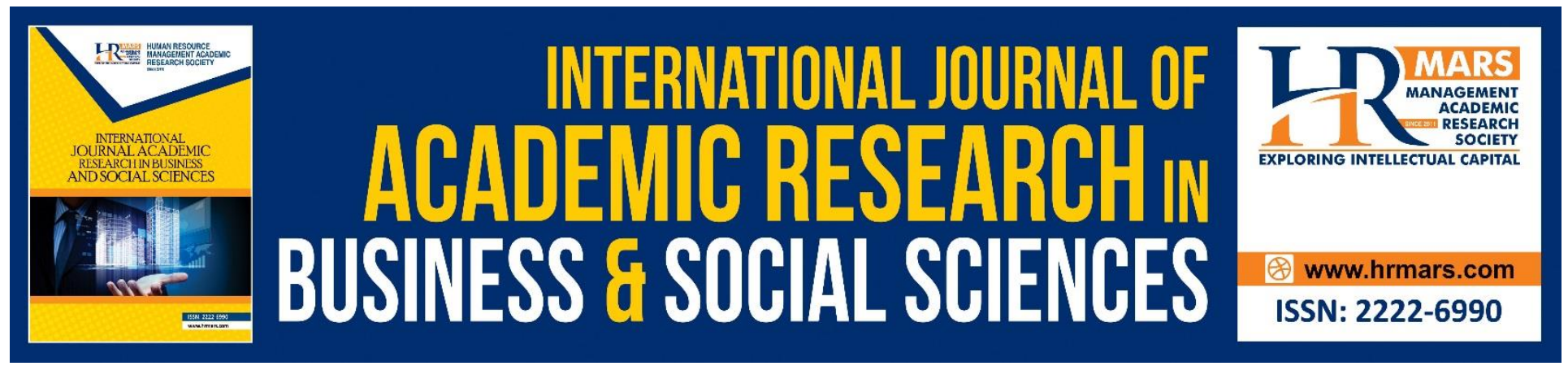

\title{
Using Multimedia to Promote Students' Learning and Understanding of English Literature in Secondary School
}

\section{Siti Nursakina Baharudin, Khairunnisa Zulkiflei, Melor Md Yunus}

To Link this Article: http://dx.doi.org/10.6007/IJARBSS/v9-i2/5525

DOI: $\quad 10.6007 /$ IJARBSS/v9-i2/5525

Received: 25 Jan 2019, Revised: 21 Feb 2019, Accepted: 24 Feb 2019

Published Online: 01 March 2019

In-Text Citation: (Baharudin \& Zulkiflei, 2019)

To Cite this Article: Baharudin, S. N., \& Zulkiflei, K. (2019). Using Multimedia to Promote Students' Learning and Understanding of English Literature in Secondary School. International Journal of Academic Research in Business and Social Sciences, 9(2), 106-114.

\section{Copyright: (C) 2019 The Author(s)}

Published by Human Resource Management Academic Research Society (www.hrmars.com)

This article is published under the Creative Commons Attribution (CC BY 4.0) license. Anyone may reproduce, distribute, translate and create derivative works of this article (for both commercial and non-commercial purposes), subject to full attribution to the original publication and authors. The full terms of this license may be seen at: http://creativecommons.org/licences/by/4.0/legalcode

Vol. 9, No. 2, 2019, Pg. 106 - 114

Full Terms \& Conditions of access and use can be found at http://hrmars.com/index.php/pages/detail/publication-ethics 


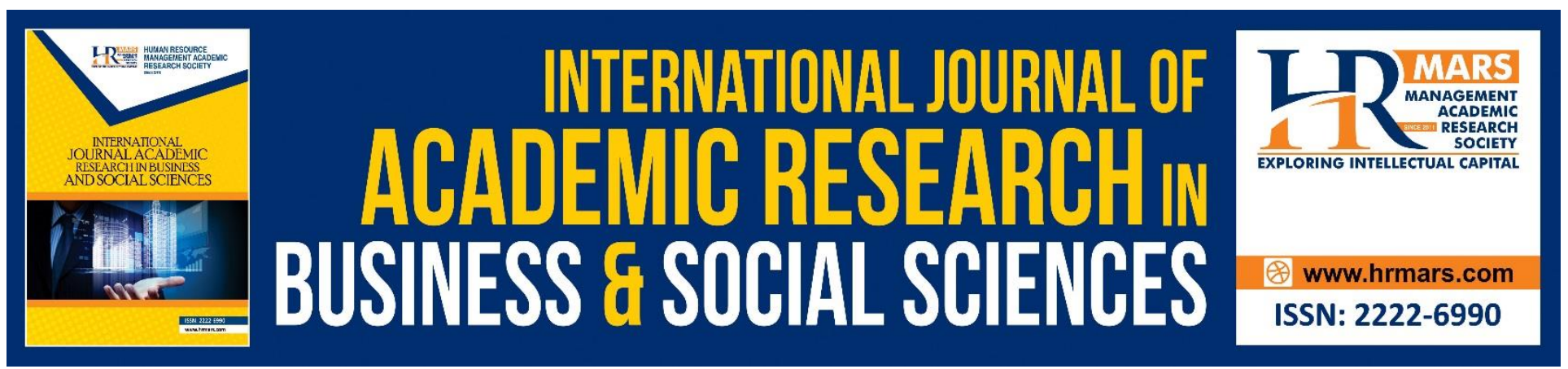

\title{
Using Multimedia to Promote Students' Learning and Understanding of English Literature in Secondary School
}

\author{
Siti Nursakina Baharudin, Khairunnisa Zulkiflei, Melor Md Yunus \\ Faculty of Education, Universiti Kebangsaan Malaysia \\ Email: sitinursakina90@gmail.com,kay_run90@yahoo.com,melor@ukm.edu.my
}

\begin{abstract}
Multimedia learning is a cognitive theory of learning which has been popularized by of Richard E. Mayer. The theory has largely been defined by Mayer's cognitive theory of multimedia learning in which multimedia learning happens when we use the combination of words and pictures to build mental representations. In this study, multimedia learning was implemented to create active learning experiences for learners in learning literature components. Thus, an innovative learning application is developed to assists secondary school learners towards better understanding of literature. With the multimedia learning approach, videos created using Powtoon application are used to teach learners literature. This instructional video is indeed effective as it encourages active participation among learners in class other than noticeable result improvement. The findings have positive implications on the English language teaching tapestry as the study lent empirical evidence to the success of language learning through teaching literature using videos.
\end{abstract}

Keywords: Digital Stories, Multimedia, Literature, Poems, Secondary School.

\section{Introduction}

The Malaysia Education Blueprint 2013-2025 has portrayed its seriousness in emphasizing the learning of English in Malaysian schools. English is rendered as a second language in Malaysia and formally taught in Malaysian schools but the declining of English proficiency among Malaysian students worries various parties especially Ministry of Education and this language proficiency issue needs to be resolved in effort to produce first class human capital (Azizan, 2013; Pawanchik, 2014). Therefore, the Ministry of Education introduced literature component in the English language syllabus as the incorporation of English literature in English language learning is seen as a great approach to tackle the language problem. Furthermore, implementing English literature in language class has been shown to successfully assist students in grasping the target language (Nair et al., 2012). 
The statement is further supported by Widdowson (1975) when he claimed "the study of literature is fundamentally a study of language in operation" which is based on the realisation that literature is an example of how a language working in a society. Thus, studying literary texts would enhance language learning and increase learner's appreciation on multiple aspects of the learned language.

The Ministry of Education Malaysia (2013) views this matter so seriously that English Literature syllabus is made compulsory to be implemented and taught in both primary and secondary school levels. However, students frequently have a hard time dealing with assigned literary texts in the literature component. Reading and understanding can be quite tough in literature classroom. A study by Sidhu (2003) showed secondary school students do not feel motivated in literature classroom because of their low language proficiency and insufficient source of attractive teaching materials. Thus, it is reasonable to insert the use of multimedia in teaching literature to attract students; attention and increase students' motivation in reading literary texts. The main objective of this study is to analyse secondary school students' performance on the use of animation in learning literary texts used in the English syllabus. Data were gathered through tests and observations to the following research question: What are the improvements in performance made by students through multimedia learning in learning literary texts?

\section{Multimedia Learning}

Multimedia learning is a cognitive theory of learning which has been popularized by Richard $\mathrm{E}$. Mayer. Generally, the theory of Multimedia learning is to help people learn efficiently by structuring multimedia instructional practices which utilizes more effective cognitive strategies. Building mental representation from words and pictures is what Multimedia learning tries to achieve. The cognitive theory of multimedia learning (CTML) believes that learners learn more effectively and efficiently when they form meaningful connections between words and pictures compared to learning with only words or pictures alone (Mayer, 2009). Multimedia can be found in various forms in education setting such as words and pictures, and can be introduced as printed or spoken text. The pictures can be presented in static form, such as illustrations, photos, diagrams, charts, or maps, or in dynamic form, such as animation or video (Mayer, 2011). The use of instructional multimedia can be presented in various formats, such as students watching a movie, reading a story book, playing an educational game, or watching and listening to educational video.

Teaching and learning using various sources and types of multimedia has increase in number since the last two decades. However, Chandler (2009) found educational videos and the use of multiple representations such as still and moving images, audio, and animations are extremely helpful in student's language learning by the dynamic content presentations. Additionally, a more recent study by Purcell (2010) found that the use of video has become the third most popular genre for learning. Many empirical studies on the use of dynamic audio-visuals has been conducted pertaining to education since the invention of television. The studies have shown that students prefer educational video over mere text as they found that they experience deeper learning from video than from words alone (Shepard, 1967; Baggett, 1984; Salomon, 1984; Wetzel, Radtke, and Stern, 1994; Mayer \& Moreno, 2002; Mayer, 2002, 2003, 2005). Researchers proposed that audio-visuals contain multiple representation: visual that conveys information about objects and its relation to other objects, and verbal that communicates abstract meaning and special attributes of this information. A combination 
of both representations should increase the learning effect (Guttormsen, Kaiser, \& Krueger, 1999; Lowe, 1999; Hegarty, Kriz, \& Cate, 2003). These theories are found to be proven successful in language learning in Malaysian school context.

\section{Multimedia Learning and Literature}

Yee, Tina and Abdullah (2012) used both quantitative and qualitative data to find out how digital stories usage in literature classroom can promote students' learning and understanding of poems in secondary school on 11 upper secondary students from a cluster school in an urban area in Johor, Malaysia. The findings of this study show the advantages of using digital story to enhance the teaching and learning of literature. This approach not only helps students to understand literature in a more effective way, but it also develops their meaning making skills through an enjoyable interactive learning experience in class. The usage of digital stories in this study were found to successfully make students understand the literary text better, improve English language, increase participation in language class, engagement in personal response and increase interest in the literature lesson.

Meanwhile, Melor, Hadi and Dexter (2013) did a study on using enhancing students' interest in reading literary texts using visual aids on 52 English language teachers from seven national secondary schools in Kapit, Sarawak, Malaysia. The selection of the respondents was based upon convenience sampling and researchers used questionnaire and semi-structured interviews. The study showed most of the teachers agreed that the use of visual aids including animations and films are relevant and enjoyable. In addition, majority of the teachers also believed that the use of visual aids improves students' performance, creates enjoyable learning environment in the literature classroom and helps the students to comprehend the cultural elements presented in the texts.

The study on the use of Youtube in teaching English literature on 120 students majoring in English language and literature from Al-Majma'ah University-Al-Majma'ah community college also showed positive outcome. Khalid and Muhammad (2012) used survey questions, pre-test, post-test, structured interview and pre-interview questions for the study. The results indicate that YouTube can help students in literature class, especially in understanding the novel events and the ability to raise the literature achievement. Students also found to enjoy watching video/clips/pictures/films on YouTube, because it gives them more enjoyment and exploring the world. YouTube makes it much easier for students to understand literary text and makes it possible for students to provide more comprehensive answers to questions related to the literary text. A number of students were happy about how YouTube offered full explanation and understanding of all the elements in the literary text.

\section{Methodology}

\section{Research Design}

This research utilized an experimental design as the aim is to investigate the use of Powtoon in promoting learning and understanding of English Literature among secondary school students in Malaysia. 
INTERNATIONAL JOURNAL OF ACADEMIC RESEARCH IN BUSINESS AND SOCIAL SCIENCES

Vol. 9, No. 2, Feb, 2019, E-ISSN: 2222-6990 C 2019 HRMARS

\section{Participants}

This study required the school students as the subject. The participants were 25 Form Five students (aged 17) from a local secondary school in Selangor district. The participants were all Malays and comprised of 17 males (68\%) and 8 females (32\%).

\section{Instrument}

The research instrument used in the study is the tests questions related to the literature in which the students were learning. The test questions were design by the teacher according to the student's level. Another instrument used in this study is the classroom learning activities checklist to see whether animation really help students in learning and understand English literature better.

\section{Procedure}

Pre-test and post-test designs are the preferred method to compare the students' test scores and to measure the degree of change occurring as a result of treatments or interventions. In this study, the pre-test and post-test were conducted. Pre-test was given to the students before the intended lesson starts. Their marks were recorder as early measurement. Then, two lessons were implemented using Powtoon video. Post-test was given right after the animation had been implemented in the lessons. The results of the students' test scores were recorded as the final measurements. The results were transferred into the form of column chart to see the difference of the increase/decrease of the score for both pre-test and post-test.

\section{Data Analysis}

The research data were analysed via both descriptive and inferential tools. Descriptive analysis was used to describe the students' pre-test and post-test results and the paired samples t-test was applied to determine the equality of variances between the two data sets. The $p$-value for significance was set at 0.05 . 
INTERNATIONAL JOURNAL OF ACADEMIC RESEARCH IN BUSINESS AND SOCIAL SCIENCES

Vol. 9, No. 2, Feb, 2019, E-ISSN: 222 2-6990 (C) 2019 HRMARS

Findings and Discussion

Findings were presented according to the students' scores on pre-test and post-test. Table 1 and Chart 1 showed the score differences between pre-test and post-test results.

\begin{tabular}{|c|c|c|c|c|c|c|c|c|c|}
\hline NO & NAME & $\begin{array}{c}\text { PRE- } \\
\text { TEST } \\
(\%) \\
\end{array}$ & $\begin{array}{c}\text { POST- } \\
\text { TEST } \\
(\%)\end{array}$ & DIFFERENCE & $\begin{array}{l}\text { NO } \\
.\end{array}$ & NAME & $\begin{array}{c}\text { PRE- } \\
\text { TEST } \\
(\%) \\
\end{array}$ & $\begin{array}{c}\text { POST- } \\
\text { TEST } \\
(\%) \\
\end{array}$ & DIFFERENCE \\
\hline 1 & $\begin{array}{l}\text { STUDENT } \\
1\end{array}$ & 4 & 6 & +2 & 14 & $\begin{array}{l}\text { STUDENT } \\
13\end{array}$ & 9 & 14 & +5 \\
\hline 2 & $\begin{array}{l}\text { STUDENT } \\
2\end{array}$ & 4 & 5 & +1 & 15 & $\begin{array}{l}\text { STUDENT } \\
14\end{array}$ & 8 & 9 & +1 \\
\hline 3 & $\begin{array}{l}\text { STUDENT } \\
3\end{array}$ & 7 & 14 & +7 & 16 & $\begin{array}{l}\text { STUDENT } \\
16\end{array}$ & 4 & 6 & +2 \\
\hline 4 & $\begin{array}{l}\text { STUDENT } \\
4\end{array}$ & 8 & 8 & - & 17 & $\begin{array}{l}\text { STUDENT } \\
17\end{array}$ & 10 & 14 & +4 \\
\hline 5 & $\begin{array}{l}\text { STUDENT } \\
5\end{array}$ & 6 & 13 & +7 & 18 & $\begin{array}{l}\text { STUDENT } \\
18\end{array}$ & 6 & 10 & +4 \\
\hline 6 & $\begin{array}{l}\text { STUDENT } \\
6\end{array}$ & 5 & 11 & +6 & 19 & $\begin{array}{l}\text { STUDENT } \\
19\end{array}$ & 7 & 14 & +7 \\
\hline 7 & $\begin{array}{l}\text { STUDENT } \\
7\end{array}$ & 0 & 2 & +2 & 20 & $\begin{array}{l}\text { STUDENT } \\
20\end{array}$ & 5 & 12 & +7 \\
\hline 8 & $\begin{array}{l}\text { STUDENT } \\
8\end{array}$ & 10 & 10 & - & 21 & $\begin{array}{l}\text { STUDENT } \\
21\end{array}$ & 4 & 9 & +5 \\
\hline 9 & $\begin{array}{l}\text { STUDENT } \\
9\end{array}$ & 10 & 11 & +1 & 22 & $\begin{array}{l}\text { STUDENT } \\
22\end{array}$ & 8 & 12 & +4 \\
\hline 10 & $\begin{array}{l}\text { STUDENT } \\
10\end{array}$ & 8 & 8 & - & 23 & $\begin{array}{l}\text { STUDENT } \\
23\end{array}$ & 10 & 12 & +2 \\
\hline 11 & $\begin{array}{l}\text { STUDENT } \\
11\end{array}$ & 2 & 9 & +7 & 24 & $\begin{array}{l}\text { STUDENT } \\
24\end{array}$ & 12 & 14 & +2 \\
\hline 12 & $\begin{array}{l}\text { STUDENT } \\
12 \\
\end{array}$ & 12 & 12 & - & 25 & $\begin{array}{l}\text { STUDENT } \\
25\end{array}$ & 10 & 14 & +4 \\
\hline 13 & $\begin{array}{l}\text { STUDENT } \\
13\end{array}$ & 6 & 13 & +7 & & & & & \\
\hline
\end{tabular}

Table 1: Pre-test and post-test scores

The table above shows the students' result for both pre-test and post-test. From the table, we can see that there were huge differences in the students' pre-test and post-results. Twenty one out of twenty five students showed some positive achievement in their post-test result and there were only three students who had no positive achievement in their post-test results. Overall, the scores for the post-test of the students increased as compared to their pre-test results due to their motivation also increased with the help of the animation used by their teacher in teaching them literature. 
INTERNATIONAL JOURNAL OF ACADEMIC RESEARCH IN BUSINESS AND SOCIAL SCIENCES

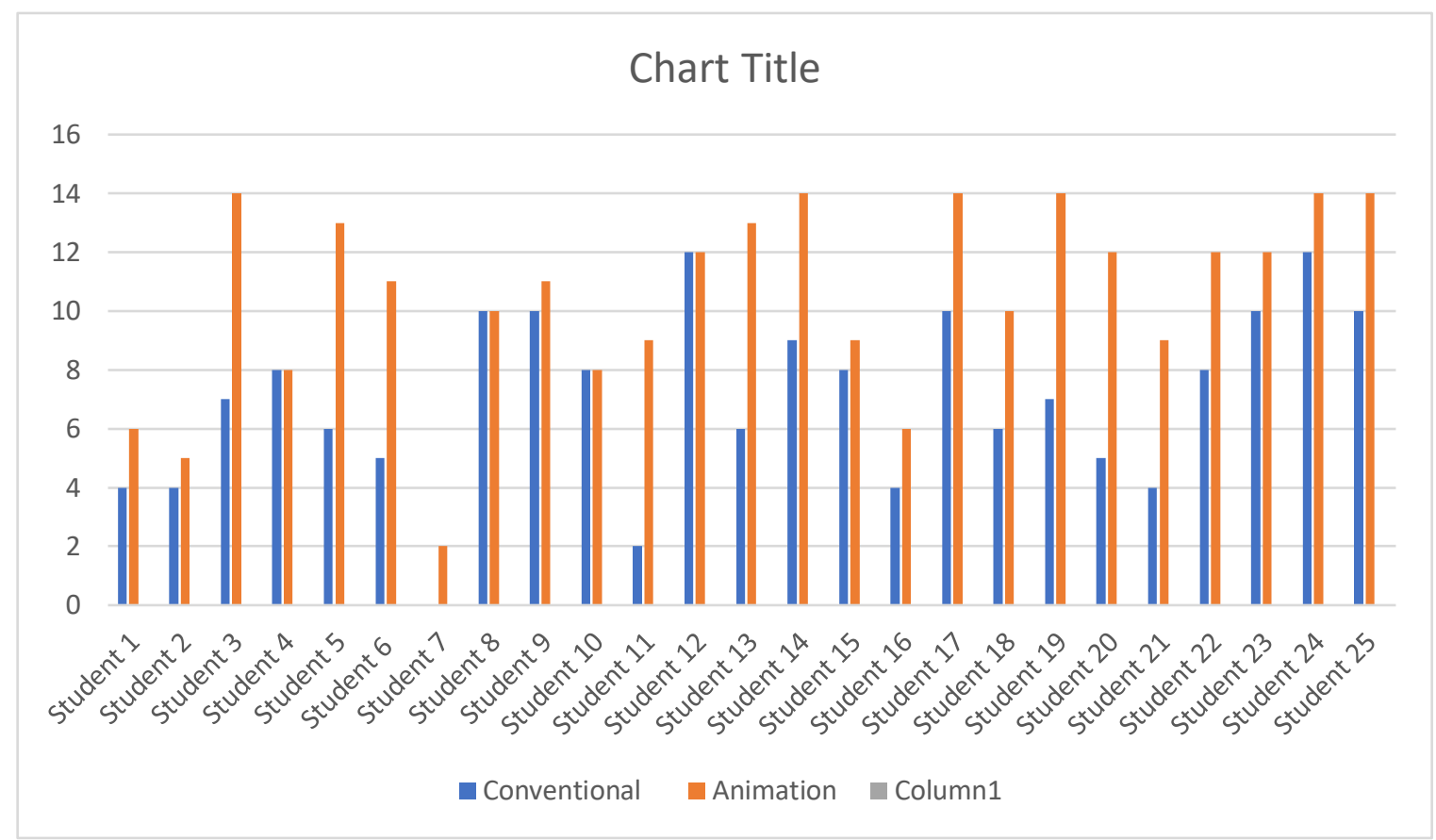

Chart 1: Students' test score using conventional and animation method

The bar chart above shows the result of both pre-test and post-test for the class. Based on the bar chart shown, we can conclude that video can be very useful in helping the students to understand literature better. The mark which is considered failed for both tests is below $50 \%$ while the passing mark is above $10 \%$. As it was just a class test. During the pre-test, the number of students who passed the test is 7 while the rest of the students failed the test. From the pre-test results, it shows that the students managed to cope with the literature lesson using conventional method. Apparently, after the treatment had been implemented, there was an increase of score in the posttest for majority of the students.

Based on the bar chart, we can see that there is an increase in the score for the students' post-test results. The findings of this study are in line with a study done by Chandler in 2009 where the study was about Dynamic visualisations and hypermedia. In the study, Chandler has found that educational videos as well as the use of multiple representations such as moving images, audio and animations are extremely helpful in students' language learning.

This study also agreed to a study done by Yee, Tina and Abdullah in 2012 where the researchers were to find out the use of digital stories in literature classroom can promote students' learning and understanding of poems in secondary school on 11 upper secondary students from a cluster school in an urban area in Johor, Malaysia. The findings of the study showed that using digital stories indeed help to enhance the teaching and learning of literature in school.

As a conclusion, it is obvious that video can help the students to understand literature better and to boost their attention span to the maximum level. Students tend to remember and understand more on the literature that they were taught in class by using video created by Powtoon. 
INTERNATIONAL JOURNAL OF ACADEMIC RESEARCH IN BUSINESS AND SOCIAL SCIENCES

Vol. 9, No. 2, Feb, 2019, E-ISSN: 2222-6990 C 2019 HRMARS

Paired-sample t-test for the students' scores on both pre-test and post-test.

Paired Samples Statistics

\begin{tabular}{|rl|r|r|r|r|}
\hline & Mean & N & Std. Deviation & \multicolumn{1}{c|}{$\begin{array}{c}\text { Std. Error } \\
\text { Mean }\end{array}$} \\
\hline \multirow{2}{*}{ Pair 1 } & PRETEST & 7.00 & 25 & 3.055 & .611 \\
& POSTTEST & 10.48 & 25 & 3.280 & .656 \\
\hline
\end{tabular}

Paired Samples Correlations

\begin{tabular}{|ll|r|r|c|}
\hline & \multicolumn{1}{|c|}{$\mathrm{N}$} & Correlation & \multicolumn{1}{c|}{ Sig. } \\
\hline Pair 1 & PRETEST \& POSTTEST & 25 & .661 & .000 \\
\hline
\end{tabular}

Paired Samples Test

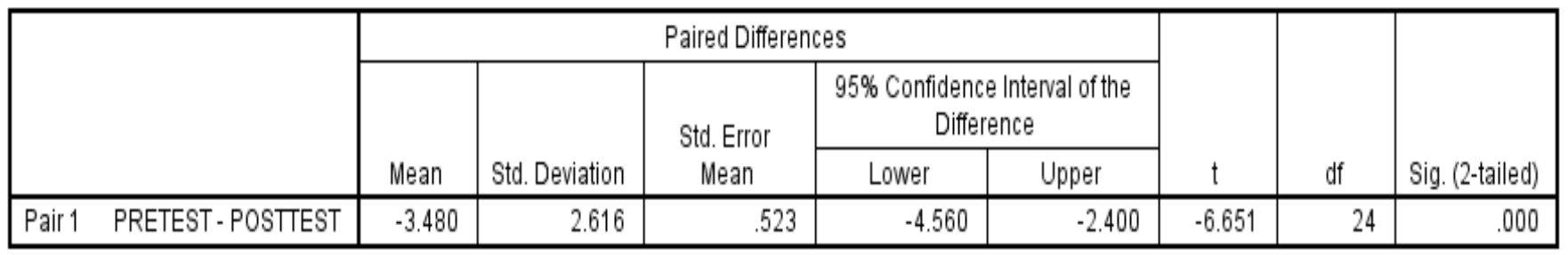

A paired-sample t-test was conducted to evaluate the impact of the intervention on students' scores on the Pre-test and Post-test. There was a statistically increase in both scores from Pre-test $(M=7, S D=3.06)$ to Post-test $(M=10.48, S D=3.28), t(24)=-6.65, p<.05$ (two-tailed). The mean increase in both Pre-test and Post-test was -3.48 with a $95 \%$ confidence interval ranging from -4.56 to -2.40 .

The eta squared statistic (1.57) indicated large effect size.

From the paired-sample t-test, it is showed that there are mean difference in the students' pre-test and post-test scores. The $p$ value is $<.05$ showed that there was significant difference between the students' pre-test and post-test scores. As explained in the bar chart earlier, the pretest scores were based on the students' understanding on literature they learnt in class using the conventional method whereas the scores for the post-test were based on the students' understanding on literature they learnt in class with the use of animation. The animations were created by the teacher using the Powtoon application to help students to learn and understand literature better. There was indeed great achievement for the post-test scores of the students after the animations were implemented in the literature lessons. The mean of the t-test showed that there was a great difference in the students' scores for both pre-test and post-test. 
INTERNATIONAL JOURNAL OF ACADEMIC RESEARCH IN BUSINESS AND SOCIAL SCIENCES Vol. 9, No. 2, Feb, 2019, E-ISSN: 222 2-6990 @ 2019 HRMARS

\begin{tabular}{|c|c|c|c|c|}
\hline $\begin{array}{c}\text { LEARNERS TASK } \\
\text { ORIENTATION/ENGAGEMENT }\end{array}$ & SCALE 1 & SCALE 2 & SCALE 3 & SCALE 4 \\
\hline $\begin{array}{l}\text { Students appear fully } \\
\text { engaged in activities. } \\
\text { Behaviours include: watching } \\
\text { the teacher, listening, } \\
\text { following along. }\end{array}$ & $\begin{array}{l}\text { None of the } \\
\text { students were } \\
\text { engaged. }\end{array}$ & $\begin{array}{l}\text { Some of the } \\
\text { students were } \\
\text { engaged. }\end{array}$ & $\begin{array}{l}\text { Most of the } \\
\text { students were } \\
\text { engaged. }\end{array}$ & $\begin{array}{l}\text { Students were } \\
\text { constantly } \\
\text { engaged. Few or } \\
\text { none were } \\
\text { disengaged. }\end{array}$ \\
\hline $\begin{array}{l}\text { Students are active } \\
\text { participant in their learning. } \\
\text { Students are actively } \\
\text { participating in their learning } \\
\text { process. }\end{array}$ & $\begin{array}{l}\text { Students were } \\
\text { passively } \\
\text { participating/not } \\
\text { actively } \\
\text { participating. }\end{array}$ & $\begin{array}{l}\text { There were some } \\
\text { instances in } \\
\text { which students } \\
\text { were actively } \\
\text { participating. }\end{array}$ & $\begin{array}{l}\text { Students actively } \\
\text { participated on } \\
\text { several } \\
\text { occasions. }\end{array}$ & $\begin{array}{l}\text { All students were } \\
\text { actively } \\
\text { participating. } \\
\text { Very few or none } \\
\text { were }\end{array}$ \\
\hline $\begin{array}{l}\text { Students appear to be } \\
\text { working/oriented towards } \\
\text { the learning goal/objective. } \\
\text { Students appear to know } \\
\text { what the goal of the } \\
\text { activity/lesson is and are } \\
\text { working on it. }\end{array}$ & $\begin{array}{l}\text { None of the } \\
\text { students were } \\
\text { working/oriented } \\
\text { towards the } \\
\text { goal/learning } \\
\text { objective. }\end{array}$ & $\begin{array}{l}\text { Some students } \\
\text { appeared to be } \\
\text { working/oriented } \\
\text { towards the } \\
\text { goal/learning } \\
\text { objective. }\end{array}$ & $\begin{array}{l}\text { Many students } \\
\text { were } \\
\text { working/oriented } \\
\text { towards the } \\
\text { goal/learning } \\
\text { objective. }\end{array}$ & $\begin{array}{l}\text { All of the } \\
\text { students were } \\
\text { working/oriented } \\
\text { towards the } \\
\text { goal/learning } \\
\text { objective. }\end{array}$ \\
\hline $\begin{array}{l}\text { Students are engaged with } \\
\text { material. Students watch, } \\
\text { listen to each other sing or } \\
\text { participate and also } \\
\text { participate. }\end{array}$ & $\begin{array}{l}\text { There were no } \\
\text { instances during } \\
\text { the observation } \\
\text { when students } \\
\text { were engaged } \\
\text { with materials. }\end{array}$ & $\begin{array}{l}\text { Students were } \\
\text { sometimes } \\
\text { engaged with } \\
\text { materials. }\end{array}$ & $\begin{array}{l}\text { Students were } \\
\text { engaged with } \\
\text { materials on } \\
\text { several } \\
\text { occasions. }\end{array}$ & $\begin{array}{l}\text { All students were } \\
\text { always engaged } \\
\text { with materials. }\end{array}$ \\
\hline $\begin{array}{l}\text { Students' attention to the } \\
\text { lesson evident. Student look } \\
\text { at lesson (or material) and } \\
\text { not elsewhere. }\end{array}$ & $\begin{array}{l}\text { No students } \\
\text { outwardly } \\
\text { appeared to be } \\
\text { paying attention } \\
\text { to the lesson. }\end{array}$ & $\begin{array}{l}\text { Some of the } \\
\text { students } \\
\text { outwardly paid } \\
\text { attention to the } \\
\text { lesson. }\end{array}$ & $\begin{array}{l}\text { Most of the } \\
\text { students } \\
\text { outwardly paid } \\
\text { attention to the } \\
\text { lesson. }\end{array}$ & $\begin{array}{l}\text { All students } \\
\text { outwardly } \\
\text { appeared to be } \\
\text { paying attention } \\
\text { to the lesson. }\end{array}$ \\
\hline $\begin{array}{l}\text { Students' sharing or answer } \\
\text { and thoughts is observed. } \\
\text { Students raised their hands } \\
\text { to answer or volunteer to } \\
\text { participate during the lesson. } \\
\text { They respond when teacher } \\
\text { asks questions. }\end{array}$ & $\begin{array}{l}\text { There were no } \\
\text { instances during } \\
\text { the observation } \\
\text { when students } \\
\text { shared or offered } \\
\text { answers. }\end{array}$ & $\begin{array}{l}\text { There were few } \\
\text { instances where } \\
\text { students shared } \\
\text { thoughts and } \\
\text { answers. }\end{array}$ & $\begin{array}{l}\text { Most of the } \\
\text { students shared } \\
\text { thoughts and } \\
\text { answers at least } \\
\text { once. }\end{array}$ & $\begin{array}{l}\text { The lesson or } \\
\text { activity could be } \\
\text { characterized by } \\
\text { nearly all of the } \\
\text { students sharing } \\
\text { answers. }\end{array}$ \\
\hline $\begin{array}{l}\text { Students are encouraged to } \\
\text { collaborate or share ideas } \\
\text { with one another during } \\
\text { observation. }\end{array}$ & Strongly disagree & Disagree & Agree & Strongly agree \\
\hline
\end{tabular}

\section{Table 2: Students' Engagement Checklist Conventional Animation}

Table 2 showed the engagement checklist of the students during the process of teaching and learning of literature in class. There were all together seven items and the 4-scales point were used to indicate the level of students' participation in the literature teaching and learning process. From the table, it is seen that students are less engaged in their lesson when the teacher used the conventional method to teach literature. The students were participated passively during the literature lesson and there were some instances where the students shared their thoughts and answers regarding the lesson. 
The students were also less encouraged to collaborate or to share ideas with one another during their literature lesson wen conventional method was applied to the lesson.

Apparently, the students became more active learners during their literature lesson when the animation was applied by the teacher in class. Most of the students were constantly engaged and they participated actively on several occasions. Some of them appeared to be working towards the learning objectives. Lastly, with the animation applied by the teacher, the literature lesson became more interesting and students started to interact among one another, instead of hesitated to share their thoughts and ideas during the literature lesson.

\section{Conclusions and Recommendations}

This study which was carried out in a local secondary school has managed to document a case of positive results among secondary school students in learning and understanding English literature better. The findings of the study showed that students learn better with videos created using Powtoon. They tend to pay more attention to the lessons compared to when their teacher uses the conventional methods.

The conclusion which can be drawn from the discussion above is that the use of Powtoon videos encourages active participation among learners in class. Learners tend to participate actively during the lesson rather than just become passive learners; they asked questions, answer teacher's questions and they even exchange thoughts and ideas with their friends. This phenomenon is quite different from what the teacher was experiencing when teaching the learners literature using conventional method, which is chalk and book. Moreover, learning literature with the help from videos created by using the Powtoon application really gives great impact to both learners and teacher. Teaching literature using Powtoon videos indeed gives noticeable result improvement as discussed in the findings earlier. However, there are still some suggestions which can be done in order to help learners to continue learning literature in more fun and interactive ways. Teacher might want to let the learners to show their talent and skills in presenting their poems or short stories by working in groups to create their own videos based on the particular topic learnt in class. The teacher can even give opportunity to the learners to express themselves by asking them to relate their own experience with the particular topics learnt using videos. Overall, teaching literature using Powtoon videos is indeed beneficial to both learners and teacher in the learning process.

Even though the findings of the study can enlighten English teachers and offer them a deeper understanding as to how to teach literature effectively, it does not seem to be certain and conclusive. It seems to be necessary to carry out more study with large sample size to really know what method can really cater the students' interest in learning English literature.

In a conclusion, the cognitive theory of multimedia learning which has been popularized by Richard E. Mayer, has been a great contribution to this research as the theory has been proven to be true in helping learners to learn better using multimedia. The theory has been proven to be in line with the major findings of this study where learners learn better using multimedia and videos and that they can even participate actively in the lessons, also, great improvement of the learners' results are also noticeable with the help of multimedia in the learning process. 
INTERNATIONAL JOURNAL OF ACADEMIC RESEARCH IN BUSINESS AND SOCIAL SCIENCES

Vol. 9, No. 2, Feb, 2019, E-ISSN: 2222-6990 C 2019 HRMARS

\section{References}

Azizan, S. A. (2013). Strengthening Malaysia's Scientific and Technological Development through Human Capital Development. Procedia-Social and Behavioral Sciences, 91, 648-653.

Baggett, P. (1984). Role of temporal overlap of visual and auditory material in forming dual media associations. Journal of Educational Psychology, 76(3), 408-417.

Chandler, P. (2009). Dynamic visualisations and hypermedia: Beyond the "Wow" factor. Computers in Human Behavior, 25(2), 389-392.

Choo, Y. B., Abdullah, T., \& Nawi, A. M. (2017). Using Digital Stories to Promote Students' Learning and Understanding of Poems in Secondary School. Sains Humanika, 9(4-2).

Guttormsen, S., Kaiser, J., \& Krueger, H. (1999). Multimedia: The effect of picture, voice \& text for the learning of concepts and principles. ETH-Zentrum 8092 Zurich: Lawrence Erlbaum Associates.

Hegarty, M., Kriz, S., \& Cate, C. (2003). The roles of mental animations and external animations in understanding mechanical systems. Cognition and Instruction, 21(4), 209-249.

Khalid, A. Z., \& Muhammad, K. (2012). The use of YouTube in teaching English literature the case of Al-Majma'ah community college, Al-Majma'ah university (case study). International Journal of Linguistics, 4(4), 525-551.

Lowe, R. (1999). Extracting information from an animation during complex visual learning. European Journal of Psychology of Education, 14(2), 225-244.

Mayer, R. E. (2009). Multimedia learning (2nd).

Mayer, R. E. (2011). Multimedia learning and games.

Mayer, R., \& Moreno, R. (2002). Animation as an aid to multimedia learning. Educational Psychology Review, 14, 87-100.

Mayer, R. (2002). The promise of educational psychology: Learning in the content areas. Upper Saddle River, N.J.: Merrill.

Mayer, R. (2003). The promise of multimedia learning: Using the same instructional design methods across different media. Learning and Instruction, 13(2), 125.

Mayer, R. (2005). The Cambridge handbook of multimedia learning. Cambridge, U.K.; New York: Cambridge University Press.

Nair, G. K. S., Setia, R., Ghazali, S. N., Sabapathy, E., Mohamad, R., Ali, M. M., ... \& Hassan, N. S. I. C. (2012). Can literature improve English proficiency: The students' perspective. Asian Social Science, 8(12), 21.

Pawanchik, S., \& MalaySia, U. S. (2006). Improving Students' Proficiency in English. In 2006 European College Teaching \& Learning Conference.

Purcell, K. (2010). The state of online video. Washington, DC: Pew Internet \& American Life Project.

Salomon, G. (1984). Television is "easy" and print is "tough": The differential investment of mental effort in learning as a function of perceptions and attributions. Journal of Educational Psychology, 76(4), 647-658.

Shepard, R. (1967). Recognition memory for words, sentences, and pictures. Journal of Verbal Learning and Verbal Behavior, 6(1), 156-163.

Sidhu, G. K. (2003). Literature in the language classroom: Seeing through the eyes of learners. Wetzel, C., Radtke, P., \& Stern, H. (1994). Instructional effectiveness of video media: Lawrence Erlbaum Associates. 
INTERNATIONAL JOURNAL OF ACADEMIC RESEARCH IN BUSINESS AND SOCIAL SCIENCES

Vol. 9, No. 2, Feb, 2019, E-ISSN: 2222-6990 @ 2019 HRMARS

Widdowson, H.G. (1975) Stylistics and the teaching of literature London: Longman

Yunus, M. M., Salehi, H., \& John, D. S. A. (2013). Using visual aids as a motivational tool in enhancing student's interest in reading literary texts. arXiv preprint arXiv:1305.6360. 